UDC 336:005.334:657.92

JEL Classification: C52, D04, D81, G32

http://doi.org/10.21272/mmi.2019.1-19

Larysa Hrytsenko,

D.Sc., Professor, Sumy State University, Ukraine

Iryna Boiarko,

Ph.D., Associate Professor, Banking University, Ukraine

Oleksiy Ryabenkov,

Ph.D., JSC «Ukrzaliznytsia», Ukraine

Oksana Didenko,

D.Sc., Raiffeisen Bank Aval, Ukraine

\title{
ASSESSMENT OF THE VALUE LOSS RISK IN RESPONSE TO THE ENTERPRISE'S INNOVATIVE TRANSFORMATIONS
}

Abstract. The aim of this research is to investigate the scientific and methodic approach to the assessment of market value loss risk in response to the enterprise's innovative transformations. The management system under conditions of innovative transformations in the economy, first of all, has to be concentrated on the management of an enterprise's market value loss risk. The article proposes the scientific and methodic approach to the comprehensive assessment of the enterprise's market value loss risk under the innovative transformations of the economy. It enables to take into account the integral influence of factors, which form the economic value added, ranked by the priority to monitor the value-oriented management of the enterprise's innovative development. This approach is based on the multi-step algorithm, which forms the data array by the expert method, the normalization of indicators, the identification of the risk degree scoring through taxometric method, the prioritization of the factor features by Fishburn's equation, generalized quantitative and qualitative assessment of the financial risk based on the minimax approach. Authors demonstrate the results of the market value loss risk assessment at the enterprises from the industrial complex of Ukraine during 2008-2017. Taking into account the obtained result, one can point out that, in general, the innovative activity of the industrial enterprises in Ukraine is described with an average level of the enterprise's market value loss financial risk (the average complex assess of the enterprise's market value loss financial risk is 0.39 of the unit fraction for the analyzed period). The reasonability and advantages of implementing the proposed scientific and methodic approach consist of the following actions: to identify the objective set of indicators, the dynamics of which proves the probability of enterprise's market value loss risks in response to the innovative transformations in the economy and can be used to make weighted managerial decisions; to define the enterprise's market value loss risk level in response to the innovative transformations in the economy both by the separate indicators and together; to define the significance of every indicator, based on mathematical calculations, in general, integral indicator through the weighted coefficient. It enables to select various factors of the innovative activity and innovations efficiency; universal nature and the possibility to use either for conclusions regarding enterprise's market value loss risk level, based on the enterprises' aggregated data or to obtain individual risk assessments of a separate enterprise in response to the innovative transformations in the economy. The stepwise nature of the risk dynamics, abrupt transitions from a low risk to the high one and vice versa during 2008-2017 points to the necessity to develop and to implement a set of measures to strengthen the control over the risk factors oriented to maintain the secure financial position and to create the industrial enterprises' market value in response to the innovative transformations in the economy at the industrial enterprises of Ukraine.

Keywords: economic value added, management of innovations, the risk of the enterprises' market value loss, risk assessment.

Introduction. The enterprises' functioning under conditions of market competition requires constant improvement of the financial management considering new strategic priorities, which are presented following the innovative transformations of the economic mechanisms, caused by impact of the historical, social and political, social and economic processes of the civilization development (globalization, internationalization, scientific and technical progress etc.). The market value as a general efficiency

Cite as: Hrytsenko, L., Boiarko, I., Ryabenkov, O., \& Didenko, O. (2019). Assessment of the Value Loss Risk in Response to the Enterprise's Innovative Transformations. Marketing and Management of Innovations, 1, 229-237. http://doi.org/10.21272/mmi.2019.1-19 

Innovative Transformations

indicator of innovative changes in the economic entities' activity becomes more popular that is due to the conception of Value-Based Management (VBM).

The enterprises' innovative and investment activity is followed by a great number of external and internal factors, which have a significant impact on the effectiveness and stability of business entities. The innovative activity of any industrial enterprise is influenced by various risks, which may be fulfilled through lack of income or capital loss, profitability and financial stability indicators deterioration, and finally, they can lead to the enterprises' market value reduction. Assessment of the market value loss risk is a basic stage to control them, which enables quantitatively and qualitatively to identify the proper risk, its factors and to define the degree of its influence on the enterprise's innovative development.

Literature Review. Theoretical principles of the company's value management were firstly demonstrated in works of A. Marshall and I. Fisher, and became a base of Miller-Modigliani models (Modigliani and Miller, 1958, 1963), Stern-Stewart conception (Stern and Stewart, 2001), dedicated to the economic value added (EVA), Copeland-Koller-Murrin conception (Copeland, Koller, Murrin, 1999) regarding the identification of the managerial instruments to implement the company's strategy. Various aspects to form the enterprise's market value, related to the objectivation of approaches and methods to its assessment, its formation and destruction factors, and mechanisms to regulate the processes of enterprise's market value creation, have been studied in many works of native and foreign scientists, such as R. Kostyrko, N. Tertychna, V. Shevchuk (2008), Ya. Samusevych (2011, 2012), G. Sychova, Ye. Kolbachev, V. Sychov (2004), V. Khaustova, I. Kurochkina (2009), V. Tsarev (2007). On the other hand, representatives of the world science did not ignore the development of the theory and methodology to assess financial risks. Particularly, such researchers as O. Bozhanova (2015), V. Vitlinsky and P. Verchenko (2008), V. Kochetkov and N. Shypova (2009), L. Donets, O. Shepelenko, S. Barantseva (2012), O. Polyakova (2011) dealt with the problems to determine the risks essence, their classifications, assessment and management methods. At the same time, despite the significant progress of the modern science in the subject area of risk-management and value-oriented management, the problems regarding enterprise's market value loss risk as a specific financial risk, which has a complex nature in terms of all factors' activity in it, which define the enterprise's financial and economic activity efficiency, its competitiveness and investment attractiveness under conditions of the innovative transformations in economy, have not been enough investigated.

Methodology and research methods. The aim of this research is to investigate the scientific and methodic approach to the assessment of market value loss risk in response to the enterprise's innovative transformations. The management system under conditions of innovative transformations in the economy, first of all, has to be concentrated on the management of an enterprise's market value loss risk. We suppose it to be a real indicator deviation of the enterprise's market value from the planned indicator, which is the base for the accepted strategy of the enterprise's innovative development, in relation to which the balanced system of indicators was developed and regulatory restrictions and planned values for it in terms of responsibility centres were established. In order to assess the risks of the enterprise's market value loss (EMVL), we suggest to use the integral indicator of the risk level, which includes the sum of factors, weighted by a certain coefficient, regarding the enterprise's financial state in terms of operative, financial and investment activity, since the enterprise's market value is a complex result of the innovative process efficiency by all directions. This approach to the complex assessment of EMVL risk enables to take into account the integral influence of factors, which form the economic value added in the enterprise's innovative development, ranged by the monitoring priority. It is based on the multistage algorithm, which provides for the data massive formation by expert method, normalization of indicators, identification of the risk scoring assessment through the taxometric approach, specification of the factor features priority by Fishburn's equation, generalizing quantitative and qualitative assessment of risk based on the minimax approach (fig. 1). 
L. Hrytsenko, I. Boiarko, O. Ryabenkov, O. Didenko. Assessment of the Value Loss Risk in Response to the Enterprise's Innovative Transformations

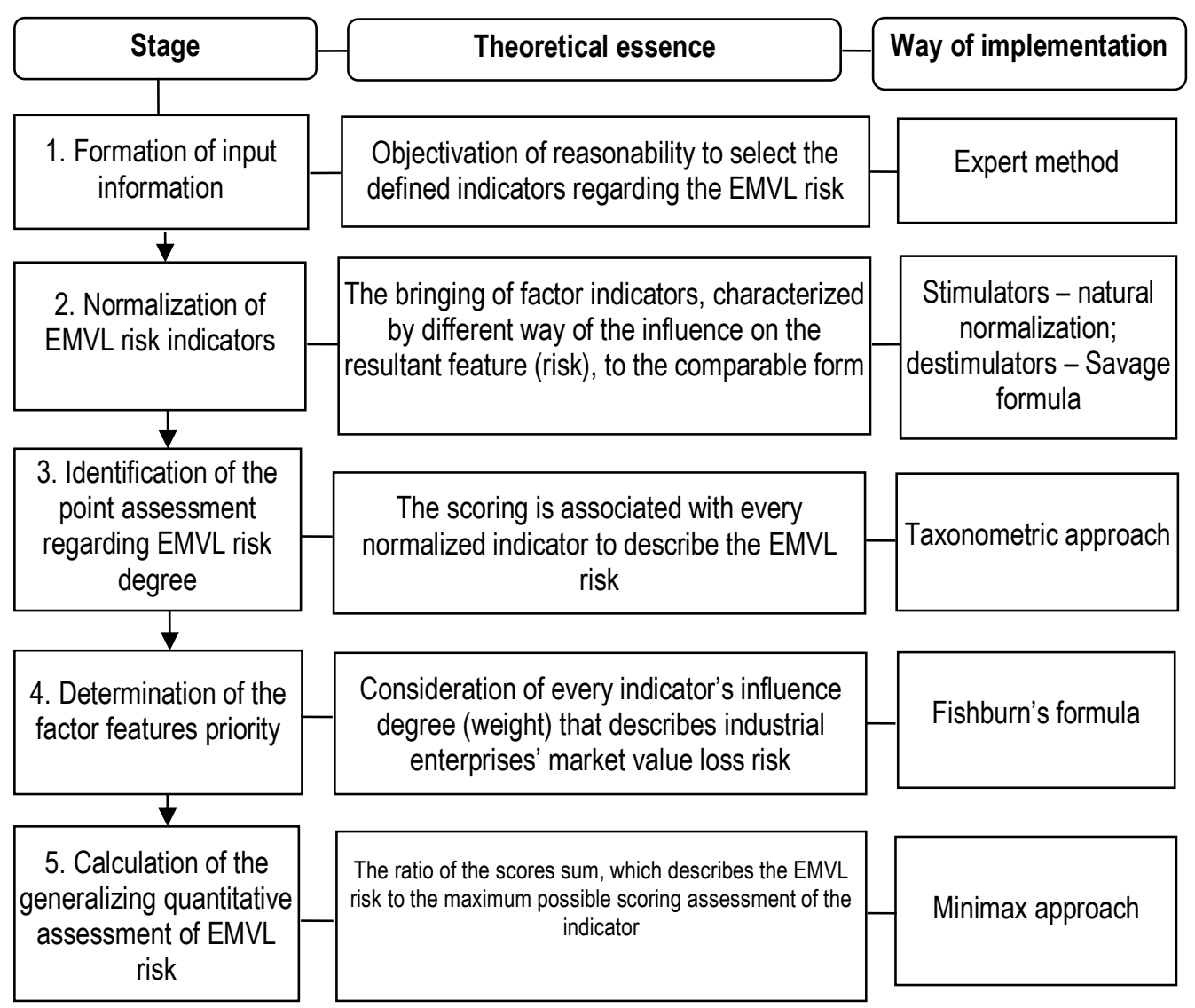

Figure 1. Stages to implement the scientific and methodic approaches for the industrial

Source: author's investigation. enterprises' market value loss risk

At the first stage, it is necessary to find and to form statistic data, to carry out their fundamental analysis from the viewpoint of information base identification to study risk, to prove the reasonability to use the defined indicators for a description of the set task and to identify their dynamics peculiarities.

Since the market value added indicator (MVA) is formed as accumulated value of the assessed economic value added (EVA), amounts flow, evaluated considering the change in the money value in time, generated in the process of enterprises' functioning within the predicted period, to our minds, in order to assess EMVL risk under conditions of innovative transformations in the economy, it is reasonable to use the following factor model:

$$
E V A=I C \cdot\left((1-T x) \cdot\left(P_{O A} \cdot\left(T_{C D} \cdot R_{O C}+S_{S G \& A} \cdot C P_{I C}\right)-I P_{I C}\right)-C_{O F} \cdot S_{O C}\right)
$$

where $I C$ - the invested capital sum, monetary units; $1-T x$ - tax corrector, units; $T x$ - profit tax rate, units; $P_{O A}$ - coefficient of the operational activity profitability, units; $T_{C D}$ - coefficient of the credit debt turnover, units; Roc-ratio of the non-interest bearing obligations and paid invested capital, units; $S_{S G \& A}$ - the share of total cost per $1 \mathrm{UAH}$ of the realized production, units; $C P_{I C}$ - coefficient of the capital 

Innovative Transformations

productivity, invested in the innovative activity, units; $I P I C$ - the sum of paid interest payments per $1 \mathrm{UAH}$ of the capital, invested in the innovative activity, units; $\mathrm{COF}$ - the cost of stakeholders' own invested funds, units; Soc - share of own cost to the extent of the capital, invested in the innovative activity, units.

The implementation of EVA financial risk integral level in the calculation is caused by its economic essence since this indicator shows the management system effect of the enterprise through the economic value added. It means that its calculation mechanism is based on dependence between the received benefit and existing risks for the investor. The absence of the value added will lead to the impossibility of return to capital, invested in the innovative activity, and its outflow.

The second stage to assess the EMVL risk is normalization of the quantitative features in relevant financial risk. The necessity to perform this stage is caused by two indicators - stimulators, numeric values of which positively influence the EMVL risk, and destimulators, numeric values of which will reduce this type of risk.

The natural normalization is proposed to be used for indicators, the increase of which is followed by the EMVL risk growth; Savage normalization formula is used for indicators, which have the inverse effect on the resultative indicator:

$$
x_{i j}^{S}=\frac{k_{i j}-\min _{j}\left\{k_{i j}\right\}}{\max _{j}\left\{k_{i j}\right\}-\min _{j}\left\{k_{i j}\right\}} \quad x_{i j}^{d}=\frac{\max _{j}\left\{k_{i j}\right\}-k_{i j}}{\max _{j}\left\{k_{i j}\right\}-\min _{j}\left\{k_{i j}\right\}}
$$

where $\mathrm{x}_{\mathrm{ij}}^{\mathrm{s}}$ - normalized i-indicator-stimulator for $\mathrm{j}$-year; $\mathrm{k}_{\mathrm{ij}}$ - absolute i-indicator for $\mathrm{j}$-year; $\mathrm{x}_{\mathrm{ij}}^{\mathrm{d}}$ - normalized i-indicator-destimulator for $j$-year; $\min _{j}\left\{\mathrm{k}_{\mathrm{ij}}\right\}$-minimum $\mathrm{i}$-indicator on the set of values of this indicator for the whole observed time interval; $\max _{\mathrm{j}}\left\{\mathrm{k}_{\mathrm{ij}}\right\}$ - maximum i-indicator on the set of values of this indicator for the whole observed time interval;

As a result of normalization, the data system is brought to the only one-dimensional unit, that later simplifies their comparison and lets to carry out mathematic transformations.

The third stage provides an assessment of the EMVL risk - to define the scoring degree of the EMVL financial risk in terms of every indicator in its quantitative description, which forms it. At this stage the scoring, calculated by the formula (3), has to comply with every normalized indicator regarding the quantitative evaluation of the EMVL financial risk:

$$
b_{i j}=\left\{\begin{array}{l}
0, x_{i j}<\bar{x}_{i} \\
{\left[\left(x_{i j}-\bar{x}_{i}\right) \cdot 10+1\right], x_{i j} \geq \bar{x}_{i}}
\end{array}=\left\{\begin{array}{l}
0, x_{i j}<\frac{\sum_{j=1}^{n} x_{i j}}{n} \\
{\left[\left(x_{i j}-\frac{\sum_{j=1}^{n} x_{i j}}{n}\right) \cdot 10+1\right], x_{i j} \geq \frac{\sum_{j=1}^{n} x_{i j}}{n}}
\end{array}\right.\right.
$$

where $b_{i j}$ - scoring of $i$-indicator for $j$-year; $x_{i j}-i$-indicator for $j$-year; $\bar{x}_{i}$ - average $i$-indicator for the time interval; [ ] - quotient; $n$ - total number of years for the observed time interval.

During the implementation of this formula, there is a necessity to define every average value of eight observed indicators beforehand based on the technique to calculate the average arithmetic simple value. The mentioned average value is a marginal level in future calculations, exceeding of which enables to establish the scoring which differs from zero in further calculations, by the following algorithm:

- the setting of the absolute deviation value of the $i$-indicator for the observed $j$-year; 

Innovative Transformations

- weighing of the absolute value, calculated at the previous step, on the correcting coefficient in size of 10 units;

- the increase of the indicator from the previous step by one unit. It enables quantitatively to describe the fact of the $i$-indicator excess for the observed $j$-year over the annual average level even with its small increase;

- consideration of every $i$-indicator to be scoring for the observed $j$-year of the integral number from the previously calculated steps.

The scoring from 1 to 10 shows the gradation of values by the degree to get close to the control value of financial risks. The value at level 1 points to the development standard or its close approximation. The distance to the standard is increasing with the growth of every value for one, thus, the influence level on the financial risk decreases.

The stage to weigh the sum of scoring indicators on the maximum possible scoring value in terms of every year foresees the following steps:

- to calculate the sum of scores in terms of the quantitative evaluation of EMVL risk, i.e., the excess degree regarding the real indicators of the average value as a maximum allowable value;

- to define the maximum possible (theoretical) assessment of EMVL risk through multiplying the total number of considered indicators (eight) by the maximum scoring in terms of every one of them;

- to find the ratio of results from the first and second steps:

$$
R *_{j}=1-\frac{\sum_{i=1}^{K} b_{i j}}{m \cdot m_{j} x\left\{b_{i j}\right\}}
$$

where $R_{j}^{*}$ - the scoring of the EMVL financial risk degree for $j$-year; $\sum_{i=1}^{K} b_{i j}$ - the sum of scores of $i$ indicators for $j$-year; $\cdot \max _{j}\left\{b_{i j}\right\}$ - maximum scoring of $i$-indicator for $j$-year; $m$ - total number of indicators.

The main contradictions, which arise at the last step to define the EMVL risk level at this stage, relate to peculiarities to identify the scores sum because the quantitative sum does not highlit the qualitative side. It means that the values sum can include one or two indicators with scorings, which are approximate to 10 , that is maximum remote from the reference value, and more indicators with scores approximate to 1. That is why there is a necessity to choose this or that indicator to the total value considering its influence degree.

Thus, the fourth stage of the proposed scientific and methodic approach defines the priority of the quantitative assessment indicators regarding the EMVL financial risk by Fishburn's equation.

$$
w_{i}=\frac{2 \cdot(K-i+1)}{K \cdot(K+1)}
$$

where $w_{i}$ - weighted coefficient of $i$-indicator; $K$ - total number of indicators to describe the EMVL financial risk; $i$ - serial number of the observed indicator.

Implementation of the above equation, based on the formed information ground, lets to conclude that the greatest influence on the EMVL risk assessment in response to the innovative transformations of the economy is made by the EVA, the quantitative value of which can be assessed at $22.22 \%$ or 0.22 of the unit fraction. Profitability of the operational activity and credit debt turnover, which accounts $19.44 \%$ and $16.67 \%$ of the influence, take the second and the third place in the rating of the financial risk indicators priority in response to the innovative transformations of the economy. The sum of paid interest payments 

Innovative Transformations

for $1 \mathrm{UAH}$ of the invested capital, which determines only $2.78 \%$ of the resultant indicator's quantitative assessment, is the least influential indicator.

The share of own funds in the capital, invested in the innovative activity, and the share of the operational cost per $1 \mathrm{UAH}$ of the realized production, have little impact within 5-10\%. Such division of the weighted coefficients is entirely justified, since the EMVL financial risks worsen the efficiency indicators first of all, i.e., in this study there are the EVA and profitability of the operational activity, and a few other indicators highlight some aspects of the enterprise's innovative activity, for which some risks are peculiar, and which are not always described by the worse general financial state at the enterprise.

Next (fifth) stage calculates the generalizing quantitative assessment of the EMVL risk. The calculation is based on the idea of the ratio between scores sum, which characterizes the presence of the EMVL financial risk, and maximum possible indicator's scoring (i.e., minimum risk), which is defined. The implementation of this stage provides the following calculations:

1) To find the sum of scores regarding the EMVL financial risk, weighted for the priority level of every indicator, i.e., the influence weighted coefficients. It defines the sum of scores products regarding all eight indicators by the proper share, carried out separately within every year:

$$
\operatorname{sum}_{j}=\sum_{i=1}^{K} w_{i} \cdot b_{i j}
$$

where $\operatorname{sum}_{j}$ - the sum of weighted scores regarding the EMVL financial risk for $j$-year.

2) To calculate the maximum possible (reference) core of the EMVL financial risk through selection of the minimum value among two possible alternatives: the product of total number of indicators by the maximum possible weighted score on the set of all eight indicators; sum of the maximum values regarding every indicator for the observed time interval, which is shown by the following formula:

$$
\operatorname{minmax}_{j}=\min \left\{\begin{array}{l}
K \cdot \max _{i}\left\{w_{i} \cdot b_{i j}\right\} \\
\sum_{i=1}^{K} \max _{j}\left\{w_{i} \cdot b_{i j}\right\}
\end{array}\right\}
$$

where $\operatorname{minmax}_{j}$ - minimum value of the maximum possible score of the EMVL financial risk for $j-$ year.

3) To calculate the generalizing indicator of the EMVL financial risk quantitative assessment:

$$
R_{j}=1-\frac{\operatorname{sum}_{j}}{\operatorname{minmax}_{j}}=1-\frac{\sum_{i=1}^{K} w_{i} \cdot b_{i j}}{\min \left\{K \cdot \max _{i}\left\{w_{i} \cdot b_{i j}\right\} ; \sum_{i=1}^{K} \max _{j}\left\{w_{i} \cdot b_{i j}\right\}\right\}}
$$

where $R_{j}$ - the level of the EMVL financial risk for $j$-year.

Results. The results of the proposed scientific and methodic approach to assessing the market value loss risk at the industrial enterprises in Ukraine, appearing during their innovative activity in 2008-2017, are demonstrated in table 1.

During 2015-2017 one can see the EMVL risk growth in the industrial complex in Ukraine, which appeared in the process of their innovative activity. It is caused by the deterioration of the financial stability indicators at the industrial enterprises, by an increase of the interest payments per $1 \mathrm{UAH}$ of the invested capital. During the analyzed period 2008-2017 the EMVL risk appeared also in 2008. It was quite natural, 

Innovative Transformations

because it was the time, when the world financial crisis, during which the situation was worsened by the total macroeconomic indicators and by reduction of economic sector enterprises' effective activity and their functioning destabilization, including in the sphere of innovations introduction, had a destructive influence. During next periods, after the risk downfall according to results of 2009 having overcome the post-crisis shock, one can see a gradual deployment of the EMVL financial risk from 0.18 to 0.41 of the unit fraction from 2009 till 2011 caused by the crisis in the world economy. After that, the studied indicator decreases to 0.28 of the unit fraction in 2013.

The EMVL financial risk of the industrial complex in Ukraine in 2014 was caused by the military and political situation aggravation in the ATO zone and annexation of the Crimea. According to results of 2017 the total risk of the market value loss at the industrial enterprises in Ukraine increased by $11.8 \%$ and was 0.57 of the unit fraction, that is the highest risk level of EMVL over the past 10 years.

Table 1. Quantitative assessment of the EMVL risk in response to the innovative transformations at the industrial enterprises in Ukraine

\begin{tabular}{|c|c|c|c|c|c|c|c|c|c|c|c|}
\hline \multirow{2}{*}{ Year } & \multicolumn{8}{|c|}{ Indicator } & \multirow{2}{*}{$\begin{array}{c}\begin{array}{c}\text { Sum of } \\
\text { indicators }\end{array} \\
\text { sum }\end{array}$} & \multirow{2}{*}{ 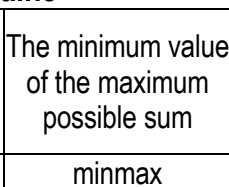 } & \multirow{2}{*}{$\begin{array}{l}\text { Quantitative } \\
\text { assessment of } \\
\text { the EMVL } \\
\text { financial risk } \\
\text { Risk }\end{array}$} \\
\hline & $\mathrm{X}_{1}$ & $\mathrm{X}_{2}$ & $x_{3}$ & $\mathrm{X}_{4}$ & $x_{5}$ & $\mathrm{X}_{6}{ }^{*}$ & $\mathrm{x}_{7}$ & $\mathrm{X}_{8}{ }^{*}$ & & & \\
\hline A & 1 & 2 & 3 & 4 & 5 & 6 & 7 & 8 & 9 & 10 & 11 \\
\hline 2008 & 0.22 & 0.19 & 1.17 & 0.00 & 0.25 & 0.14 & 0.33 & 0.00 & 2.31 & 5.19 & 0.44 \\
\hline 2009 & 0.00 & 0.00 & 0.00 & 0.00 & 0.00 & 0.14 & 0.33 & 0.00 & 0.47 & 2.67 & 0.18 \\
\hline 2010 & 0.22 & 0.00 & 0.00 & 0.11 & 0.00 & 0.00 & 0.11 & 0.11 & 0.56 & 1.78 & 0.31 \\
\hline 2011 & 0.22 & 0.19 & 0.00 & 0.00 & 0.33 & 0.28 & 0.00 & 0.06 & 1.08 & 2.67 & 0.41 \\
\hline 2012 & 0.22 & 0.00 & 0.00 & 0.22 & 0.33 & 0.42 & 0.00 & 0.03 & 1.22 & 3.33 & 0.37 \\
\hline 2013 & 0.22 & 0.00 & 0.00 & 0.28 & 0.00 & 0.42 & 0.00 & 0.03 & 0.94 & 3.33 & 0.28 \\
\hline 2014 & 1.33 & 0.00 & 0.00 & 0.11 & 0.00 & 0.42 & 0.00 & 0.00 & 1.86 & 5.19 & 0.36 \\
\hline 2015 & 1.78 & 0.00 & 0.00 & 0.11 & 0.00 & 0.42 & 0.00 & 0.00 & 2.31 & 5.19 & 0.44 \\
\hline 2016 & 2.00 & 0.00 & 0.00 & 0.22 & 0.00 & 0.42 & 0.00 & 0.03 & 2.67 & 5.19 & 0.51 \\
\hline 2017 & 2.22 & 0.00 & 0.00 & 0.00 & 0.17 & 0.56 & 0.00 & 0.00 & 2.94 & 5.19 & 0.57 \\
\hline Вага & 0.22 & 0.19 & 0.17 & 0.06 & 0.08 & 0.14 & 0.11 & 0.03 & $x$ & $\mathrm{x}$ & $x$ \\
\hline
\end{tabular}

Note: $x_{1}$ - economic value added; $x_{2}$ - profitability of the operational activity; $x_{3}-$ the credit debt turnover; $x_{4}$ - the ratio between obligations and paid capital; $x_{5}$ - coefficient of the total capital productivity; $\mathrm{x}_{6}$ - share of the operational cost per $1 \mathrm{UAH}$ of the realized production; $\mathrm{x}_{7}$ - share of own funds in the capital, invested in the innovative activity; $x_{8}$ - sum of the interest payments per $1 \mathrm{UAH}$ of the capital invested in the innovative activity; ${ }^{*}$ - indicators-destimulators.

Source: own calculations by data (Official website of State Statistics Service of Ukraine)

The authors proposed to use the following risk gradation regarding the parameter's variation for qualitative interpretation of the quantitative indicator for the EMVL financial risk assessment (Table 2).

Taking into account the obtained result, one can point out that, in general, the innovative activity of the industrial enterprises in Ukraine is described with an average level of the EMVL financial risk (the average complex assess of the EMVL financial risk is 0.39 of the unit fraction for the analyzed period). 
L. Hrytsenko, I. Boiarko, O. Ryabenkov, O. Didenko. Assessment of the Value Loss Risk in Response to the Enterprise's Innovative Transformations

Table 2. Quantitative assessment of the market value loss risk at the industrial enterprise

\begin{tabular}{|c|c|}
\hline Quantitative assessment & Type of risk \\
\hline $\mathrm{R} \leq 0.15$ & Risk is absent \\
\hline $0.15<\mathrm{R} \leq 0.35$ & Low risk \\
\hline $0.35<\mathrm{R} \leq 0.55$ & Average risk \\
\hline $0.55<\mathrm{R} \leq 0.75$ & High risk \\
\hline $\mathrm{R}>0.75$ & Catastrophic risk \\
\hline
\end{tabular}

Sources: (Boiarko, 2011)

Conclusions. The reasonability and advantages of implementing the proposed scientific and methodic approach consist of the following actions:

- to identify the objective set of indicators, the dynamics of which proves the probability of EMVL risks in response to the innovative transformations in the economy and can be used to make weighted managerial decisions;

- to define the EMVL risk level in response to the innovative transformations in the economy both by the separate indicators and together;

- to define the significance of every indicator, based on mathematical calculations, in general, integral indicator through the weighted coefficient. It enables to select various factors of the innovative activity and innovations efficiency;

- universal nature and the possibility to use either for conclusions regarding EMVL risk level, based on the enterprises' aggregated data or to obtain individual risk assessments of a separate enterprise in response to the innovative transformations in the economy.

The stepwise nature of the risk dynamics, abrupt transitions from a low risk to the high one and vice versa during 2008-2017 points to the necessity to develop and to implement a set of measures to strengthen the control over the risk factors oriented to maintain the secure financial position and to create the industrial enterprises' market value in response to the innovative transformations in the economy at the industrial enterprises of Ukraine.

Author contribution: L.H. - conceptualization and idea; L.H. I.B., O.R., O.D. - methods, results and conclusion

\section{References}

Bozhanova, O.V. (2015). Upravlinnya finansovymy ryzykamy promyslovogo pidpryyemstva: teoretychnyj aspekt [Risk management in industrial enterprise: theoretical aspect]. Naukovyj visnyk Xersonskogo derzhavnogo universytetu - Scientific Bulletin of Kherson State University, 10, 1, 80-83 [in Ukrainian].

Boiarko, I.M., \& Hrytsenko, L.L. (2011). Investycijnyj analiz [Investment analysis]. Kyiv: Centr uchbovoyi literatury [in Ukrainian]

Boiarko, I.M., \& Samusevych, Ya.V. (2011). Rol nematerialnyx aktyviv u stvorenni cinnosti kompaniyi [The role of intangible assets for value creation of the company]. Aktualni problemy ekonomiky - Actual Problems of Economics, 3, 86-94 [in Ukrainian].

Boiarko, I.M., \& Samusevych, Ya.V. (2012). Teoretychni aspekty systemy cinnisno-oriyentovanogo upravlinnya pidpryyemstvom [Theoretical aspects of value-oriented management]. Biznes Inform - Business Inform, 9, 282-284 [in Ukrainian].

Vitlinskyj, V.V., \& Verchenko, P.I. (2008). Analiz, modelyuvannya ta upravlinnya ekonomichnym ryzykom [Analysis, modeling and management of economic risk]. Kyiv: KNEU [in Ukrainian].

Kostyrko, R.O., Tertychna, N.V., \& Shevchuk, V.A. (2008). Kompleksna ocinka vartosti pidpryyemstva [Integrated assessment of enterprise value]. Kharkiv: Faktor [in Ukrainian].

Kouplend, T., Koller, T., \& Murrin, D. (1999). Stoimost kompaniy: ocenka i upravlenie [Company value: evaluation and management]. Moscow: Olimp-Biznes [in Russian].

Kochetkov, V.N., \& Shipova, N.A. (2009). Ekonomicheskiy risk i metody ego izmereniya [Economic risk and methods of its measurement]. Kyiv: Evrop. un-t [in Russian].

Donecz L.I., Shepelenko O.V., Baranceva S.M., Sergyeyeva O.V., \& Veremejchyk O.F. (2012). Obgruntuvannya gospodarskyx rishen ta ocinyuvannya ryzykiv [Substantiation of business decisions and risk assessment]. Kyiv: Centr uchbovoyi literatury [in Ukrainian].

Oficijnyj sajt Derzhavnoyi sluzhby statystyky Ukrayiny [Official website of State Statistics Service of Ukraine]. ukrstat.gov.ua. Retrieved from http://www.ukrstat.gov.ual [in Ukrainian] 
L. Hrytsenko, I. Boiarko, O. Ryabenkov, O. Didenko. Assessment of the Value Loss Risk in Response to the Enterprise's Innovative Transformations

Polyakova, O.Yu., Chujko, I.M., \& Gol'tyayeva, L.A. (2011). Mexanizm ocinky finansovogo ryzyku pidpryyemstva [The mechanism for assessing the financial risk of an enterprise]. Biznes Inform - Business Inform, 5, $21-22$ [in Ukrainian].

Sycheva, G.I., Kolbachev, E.B., \& Sychev, V.A. (2004). Ocenka stoimosti predpriyatiya (biznesa) [Estimated value of business]. Rostov n/D: «Feniks». Seriya «Vysshee obrazovanie» [in Russian].

Xaustova, V.E., \& Kurochkina, I.G. (2009). Ocinka vartosti biznesa subyektiv gospodaryuvannya (na prykladi metalurgijnoyi galuzi Ukrayiny) [Business valuation of economic entities (case study of metallurgical industry of Ukraine)]. Kharkiv: VD «INZhEK» [in Ukrainian].

Carov, V.V. (2007). Ocenka stoimosti biznesa: Teoriya i metodologiya [Business valuation: Theory and Methodology]. Moscow: YuNITI-DANA [in Russian]

Modigliani, F., \& Miller, M. (1963). Taxes and the Cost of Capital: A Correction. Ibid, June, 433-443.

Modigliani, F., \& Miller, M. (1958). The Cost of Capital, Corporation Finance and the Theory of Investment. American Economacal Reveu, June, 261-297.

Stern, Joel M., Shiely, John S., \& Ross, Irwin (2001). The EVA challenge: implementing value added change in an organization. New York: John Wiley\&Sons, Inc. Wiley finance.

Л. Л. Гриценко, д.е.н., профресор, Сумський державний університет (Україна);

І. М. Боярко, к.е.н., доцент, ДВНЗ «Університет банківської справи» (Україна);

О. В. Рябенков, к.е.н., АТ «Укрзалізниця» (Україна);

О. М. Діденко, д.е.н., Харківська обласна дирекція АT «Райфффайзен Банк Аваль» (Україна).

Оцінювання ризику втрати вартості в умовах інноваційних трансформацій підприємства

Система менеджменту в умовах інноваційних трансформацій економіки має бути зосереджена, у першу чергу, на управлінні ризиком втрати ринкової вартості підприємства. У статті запропоновано науково-методичний підхід до комплексного оцінювання ризику втрати ринкової вартості підприємства в умовах інноваційних трансформацій економіки. Він дозволяє враховувати інтегральний вплив чинників формування економічної доданої вартості, ранжованих за пріоритетністю моніторингу в системі вартісно-орієнтованого менеджменту інноваційного розвитку підприємства. Підхід заснований на багатосходинковому алгоритмі, який передбачає формування масиву даних експертним методом, нормалізацію показників, ідентифікацію бальної оцінки ступеня ризику за допомогою таксонометричного підходу, визначення пріоритетності факторних ознак за формулою Фішберна, узагальнюючу кількісну та якісну оцінку фрінансового ризику на основі мінімаксного підходу. Авторами представлено результати оцінювання ризику втрати ринкової вартості підприємств промислового комплексу України за період 2008-2017 рр. Враховуючи отримані результати, можна відмітити, що в цілому інноваційна діяльність промислових підприємств України характеризується середнім рівнем фінансового ризику втрати ринкової вартості підприємства (у середньому комплексна оцінка фрінансового ризику втрати ринкової вартості підприємства за аналізований період становить 0,39 частки одиниці). Доцільність та переваги застосування запропонованого науково-методичного підходу полягають в наступному: ідентифрікація об'єктивного набору показників, динаміка яких свідчить про імовірність виникнення ризиків втрати ринкової вартості підприємства в умовах інноваційних трансформацій економіки та може бути використана для прийняття виважених управлінських рішень; можливість визначення рівня ризику втрати ринкової вартості підприємства в умовах інноваційних трансформацій економіки як за окремими показниками, так і в сукупності; визначення на основі математичних розрахунків значущості кожного показника у загальному інтегральному індикаторі у вигляді вагового коефріцієнта, що дає змогу підбору різноманітних факторів інноваційної активності та ефективності інновацій; універсальний характер і можливість використання як для формування висновків стосовно рівня ризику втрати ринкової вартості підприємства на підставі агрегованих даних статистичної сукупності підприємств, так і для отримання індивідуальних оцінок ризику окремого підприємства в умовах інноваційних трансформацій економіки. Стрибкоподібний характер динаміки ризику, різки переходи від низького рівня ризику до високого і навпаки протягом 2008-2017 рр. вказують на необхідність розробки та реалізації на промислових підприємствах України комплексу заходів із посилення контролю за чинниками виникнення ризику, спрямованих на збереження безпечного фрінансового стану та створеної ринкової вартості підприємств промислового комплексу в умовах інноваційних трансформацій економіки. вартість.

Ключові слова: менеджмент інновацій, оцінка ризику, ризик втрати ринкової вартості підприємств, економічна додана

Manuscript received: 18.10.2018.

(C) The author(s) 2018. This article is published with open access at Sumy State University. 